\title{
Political Tolerance, National Unity and Social Cohesion as a Tool for Democratic Consolidation in Sierra Leone
}

\author{
Public Lecture Delivered at the District Council Hall, Magburaka on The 7th September, 2020 on the Theme- "Political \\ Tolerance, National Unity and Social Cohesion as a Tool for Democratic Consolidation in Sierra Leone" Conducted by the \\ Northern Regional Office of the National Commission for Democracy(NCD), Sierra Leone \\ ${ }^{1}$ Dr. Allieu Badara Kabia, ${ }^{2}$ Ibrahim Mansaray \\ ${ }^{1}$ Dean of Faculty of Social and Management Sciences \& Senior Lecturer at Ernest Bai Koroma University of Science and \\ Technology, Makeni University College, Sierra Leone, West Africa \\ ${ }^{2}$ Lecturer, Department of Sociology and Social Work, Ernest Bai Koroma University of Science and Technology, Makeni \\ University College, Sierra Leone, West Africa
}

\begin{abstract}
Over the years, despite the positive gains made in terms of democratic tools and good governance in Sierra Leone as indicated on the national emblem (Peace, Unity and Justice), the country have been fraught with difficulties and challenges. This is an academic paper presentation that gives a clear understanding of the practical implication of Sierra Leone's strides towards political tolerance, national unity, Social cohesion and democratic good governance as evidence based on the baseline study conducted by the National Commission for Democracy, as well as underscoring the challenges, recommendations and its policy implication for National security and sustainable development in Sierra Leone. It is imperative to note that National Security and Sustainable Growth and development highly depend on the fundamentals of the three main indicators as aforesaid for democratic consolidation in Sierra Leone. It's worthy to note that Political tolerance leads to National unity and National unity leads to Social Cohesion and Democratic good governance.
\end{abstract}

Keywords: Political tolerance, Nation unity, Social cohesion, Democratic Consolidation, Good governance and Sierra Leone.

\section{INTRODUCTION}

Sierra Leone has been regarded as a politically divided society along ethnic lines often containing deep personal enmity that stands in the way of other persons intending to equally benefit from political and economic opportunities based on ethnic or regional orientation. Unfortunately, experience backed by empirical evidences have shown that relationships which stems from the presence of pervasive negative reactive attitudes between key political actors, including historical grievance, personal and political vendetta, resentment or hatred are not properly addressed throughout the transitional justice process and post-conflict peace building period in Sierra Leone.

As a result, one could observe deep-rooted anger, fear, humiliation, insecurity and a sense of powerlessness among some people owing to so many unresolved peace building issues. The National Commission for Democracy (NCD) has noted that some political actors are putting up resistant attitude that continue to curtail the rights of others; others to some extent playing conspiracy of silence on politically motivated violence, whilst others directly instigate and use unemployed youths to break the laws of Sierra Leone towards achieving personal political gains. NCD has also observed that arrogance in some political actors with the ideal that their rights are more significant than others, has potentially led to and will continue to undermine democratic principles in the country. These observations thus call for significant measures such as Public Lectures of this nature to educate citizens about these challenges and to also deepen understanding of the danger of political intolerance in a post conflict society like Sierra Leone.

Some of these challenges were clearly articulated in the keynote address of His Excellency the President, during the National Consultative Conference (Bintumani III), where he lamented that; some political actors are at the heart of the acrimony that continues to mar the social peace and harmony of this country. They make everything political - the ethnicity of people, the region they come from, what they believe in, what they say, even people's last names and the colour of clothes people wear; while some of our elections are still characterized by low levels of violence and intimidation, the growing politicization of ethnicity and ethno-regionalism have become recurrent albeit objectionable patterns of our politics; governance processes have been characterized by discriminatory and divisive practices that have unfairly and unjustly excluded sections of our population. 
ISSN (online): 2581-3048

Sierra Leone was acclaimed as one of the major success stories of the United Nations in terms of its peace building efforts across the world. This small West Africa state with a present population of approximately 7 million ${ }^{1}$ people was plunged into the abyss of war (1990-2002) that caused massive destruction of lives and properties coupled with a complete breakdown of law and order.

The 2004 Truth and Reconciliation Commission Report noted that one of the key reasons for the brutal civil war of the 1990s was the lack of "a culture of tolerance and inclusion in political discourse.” The report also deplored ethnically driven politics, exclusion and patrimony. ${ }^{2}$ Thus, promoting National Unity and Cohesion is a prerequisite for consolidating peace and democracy in a post-conflict country like Sierra Leone. As such this paper seeks to elucidate the nexus among three (3) indicators; Political tolerance, National Unity and Cohesion as a pilar for consolidating the country's fledgling democracy and its hard-won peace.

\section{AIM AND OBJECTIVES OF THE STUDY}

\subsection{Aim}

This paper seeks to make conceptual and practical clarification to what Social Cohesion, National Unity and Political Tolerance mean to the Sierra Leonean context and proffer context specific recommendations to promote political tolerance, national unity and cohesion as a tool for Democratic consolidation in the country.

\subsection{Specific Objectives of the Public Lecture}

i. To convey the wishes and aspirations of the people for a united, cohesive and tolerant nation on the foundation of democratic good governance;

ii. To crystalize thoughts on the past, present and future of national unity and cohesion as a tool for the consolidation of democracy in Sierra Leone;

iii. To chart the national course in identifying and overcoming the challenges to national unity and cohesion through the lens of democratic consolidation in Sierra Leone;

iv. To provide a platform for the discussion of the allimportant subject of National Unity and Cohesion as a tool for Democratic Consolidation;

v. To promote the discussion on national unity and cohesion within a good governance context by way of changing the narrative for best practice in Sierra Leone.

\footnotetext{
${ }^{1} 2015$ Population Household Survey by Statistics Sierra Leone
}

${ }^{2}$ Truth and Reconciliation Report for Sierra Leone; 2004. Volume 1

\section{UNDERSTANDING OF KEY TERMS}

\section{A. Political Tolerance}

The Merriam-Webster dictionary (2017) offers one definition of politics as "competition between competing interest groups or individuals for power and leadership" (n.p.). The implication of this definition is that politics is a zero-sum game, wherein one party wins at the expense of the other party. This is perhaps the most obvious example, only one winner can emerge in any electoral contest; the other candidates are by definition losers.

Political tolerance means accepting and respecting the basic rights and civil liberties of persons and groups whose viewpoints differ from one's own. All citizens, including political leaders, have a responsibility to practice political tolerance in their words and actions. As a clear rejection of "might makes right," political tolerance is a key principle of democracy.

As an ideal, democracy upholds that members of the society should treat each other, and be treated, as equals. Underlying democracy is the acceptance and respect of the other. Democratic life is both the right to differ as well as the acceptance of such difference by all. Democracy implies respect for the plurality of views and virtues of dialogue as a means of resolving conflict.

Political intolerance is engendered by a willingness to restrict the rights of a disliked person or group based on their differing views. It represents a threat to democracy since it discriminates against and may even silence certain parts of the population as in the case of most countries in Sub-Sahara Africa in which Sierra Leone is not an exception within its political evolution. Intolerance creates a conformist culture and a closed society, which narrows citizens' perceptions of politics and shapes their subsequent behavior.

\section{Developing Political tolerance}

A culture of tolerance involves debate and dynamic exchanges of opinions and arguments, whereby people can learn from others, get closer to the truth, and benefit from a vital public life. Developing a culture of tolerance is a long term undertaking that removes the roots of intolerance and is necessary for the democratic process.

Some of the key ingredients of a culture of tolerance are:

\section{Education}

Education and political participation can cultivate tolerance among citizens. States can help to eliminate discrimination and hatred by promoting dialogue with 
minority and vulnerable groups. Citizens who have more opportunities to practice and observe tolerance are more appreciative of and committed to tolerance and respect for others' rights. States can contribute to the overall democratic learning and stability by involving citizens in the democratic process and upholding the civil liberties of all groups.

\section{Freedom of expression}

A society in which freedom of expression is not guaranteed hinders political tolerance. Open dialogue and a diversity of political opinions are made possible by and reinforce a culture of tolerance.

\section{Media}

The media plays an important role in developing a culture of tolerance. States have a duty to allow a pluralistic media to flourish and present diverse and critical views. Encouraging a wide array of ideas and beliefs among individuals and institutions builds an equitable and nondiscriminatory environment that enhances political life.

\section{Political Tolerance and Parliament}

Political life involves confrontation, and this is perfectly normal. Institutions of democracy, such as parliaments, provide the channels to make confrontation between opinions possible. Parliament is meant to regulate tensions and maintain equilibrium between competing claims of diversity, and to accommodate the participation of all people in the society it represents. Political tolerance is therefore essential to the functioning of parliaments and should be actively pursued in practice.

\section{Parliamentary immunity and freedom of expression}

Freedom of expression is the working tool of members of parliament, without which they cannot represent their constituents. Members of parliament need some measure of protection to carry their work, most importantly, protection of their freedom of speech. Thus, parliamentarians generally enjoy immunity from prosecution or other proceedings for votes they cast, statements they make in parliament and acts carried out as part of their parliamentary function. Parliamentary immunity safeguards the integrity and effectiveness of the parliamentary institution. However, this immunity is not an individual privilege granted for personal benefit and is not meant to place parliamentarians above the law. Rather, it protects them from politically motivated proceedings or accusations. Parliamentary immunity is vital for enabling parliamentarians to speak freely according to their conscience, without fear of harassment, punishment or other retaliatory measures.

\section{Party control over the parliamentary mandate}

The freedom of conscience and expression of parliamentarians is frequently limited in practice by political parties, which seek to exercise control over their members. Although in theory parliamentarians generally have a free representational mandate, various rules and practices have been put in place to ensure that members support the "party line". By controlling the terms of their mandate or party membership, parties can prevent parliamentarians from fulfilling their mandate and undermine the democratic process as a whole.

\section{Rights and duties of the opposition}

The freedom of expression of parliamentarians, almost exclusively those from the Opposition, frequently comes under attack. This is a particular concern because the Opposition in parliament is an indispensable component of democracy. Opposition and minority parties play a key role in holding the government to account, and in providing alternative policy options for public consideration. The opposition therefore has rights and duties that enable it to make an effective contribution to the democratic process.

\section{B. National Cohesion and Unity}

Generally speaking, the concept of National Cohesion goes beyond peace-keeping and conflict management. That is to say, it is both a process and an outcome of instilling and enabling all citizens in a country to have a sense as well as a feeling that they are members of the same country, engaged in a common enterprise and facing shared challenges. This concept is based on the fact that societies and individuals can only achieve their potential when living and working together. This is realized through the regulation and reconciliation of differences, competing interests and demands.

National Cohesion becomes stronger when everyone in the country has the opportunity, the resources and the motivation to participate in society as fully as they wish and on an equal basis with others3. A system within the society that safeguards and allows the power of the people to exist could be referred to as social cohesion. The central aim of social cohesion is to guarantee the well-being of all manner of persons within the society and not just a chosen few.

\section{National Unity}

National unity is a type of coalition government, which means that parliamentary parties or cabinets are working together in order to achieve an outcome. This type of

\footnotetext{
${ }^{3}$ Social Cohesion and Democracy by International Institute for Democracy and Electoral Assistance, (2009),
} 
ISSN (online): 2581-3048

government is usually formed during times of difficulty, such as during wars or when there are economic problems. A national unity government means that all or most of the parties in the government are working together. This is done in times of difficulty to demonstrate political legitimacy, which means that decisions made by the government have to be approved by a number of people with different backgrounds.

A national unity government, government of national unity (GNU), or national union government is a broad coalition government consisting of all parties (or all major parties) in the legislature, usually formed during a time of war or other national emergency.

\section{National Values}

National Values are beliefs of a nation guiding the actions and behavior of its citizens. It can also be defined as a representation of the Paramount values upheld throughout the common cultural experience of the nation. It refers to an accepted principles or standards of a group of people. The National values and principles of governance bind all state organs, state officers, Public officers and all persons whenever any of them;

a) Applies or interprets the constitution

b) Enacts, applies or interprets any law or makes or implements public policy decisions

It is a personal measure of worth, such as how important an individual considers certain things, beliefs, principles or ideas people attach to things based on their sense of values. These values could be categorized into;

i. Patriotism, National Unity, Sharing and Devolution of power, The rule of law, Democracy, participation of the people

ii. Human dignity, Equity and Inclusion, Social Justice, Inclusiveness, Social justice, Inclusiveness, Equality, Human rights, Non- discrimination, protection of the marginalized

iii. Good governance, Integrity, Transparency, Accountability

iv. Sustainable development

\section{Origin and Meaning of Democracy}

This term originated from the Greek Language and it comprised of two words that is "Demos" meaning people or citizens and "Kratos" meaning power or rule. To put it nicely it means people's or citizen's power to rule or govern.In the words of former United States President Abraham Lincoln dubbed as father of democracy he described democracy as " $a$ system of government of the people, by the people and for the people”.

\section{Democratic Good Governance}

In a democratic system of governance, the government must respect the principles of freedom, justice and tolerance in order to safeguard the peaceful coexistence of its citizens. It is also the responsibility of every citizen to acknowledge a good code of conduct that guarantees freedoms in a legal and institutional framework that is independent, impartial and credible. Democracy can said to be stable within a society where there is social or national cohesion and unity amongst its citizenry. The promotion of good governance goes beyond the government sector and includes all relevant actors from the private sector and society, with an overarching aim of balancing interests and focus on common goals, particularly reducing poverty and providing access to state services for all and make administrative structures participative, efficient and solution oriented ${ }^{4}$.

Democracy must be understood as a process where 'human rights' means infusing each and every aspect of life with concrete opportunities. Democracy must create conditions that allow men and women to fully enjoy their rights as citizenship and lived a 'dignified life' which will in turn allow them to contribute their own identity to public life." (IIEDA, 2009.P.5). ${ }^{5}$

\section{The Road to National Cohesion and Unity for a Democratic Sierra Leone}

Approximately, 16 months ago the President of Sierra Leone Brigadier Retired Dr. Julius Maada Bio conveyed a Consultative National Dialogue on Democratic Consolidation for Peace and National Cohesion in Sierra Leone. The national dialogue was held from May 23 to 252019 at Bintumani International Conference Center in Freetown. The conference referred to as Bintumani III aimed at uniting the country which has been divided along political and ethnical lines following the general elections which took place in 2018 .

Previously, the country had held National Conferences for Peace and Social Cohesion (Bintumani I and Bintumani II) during and after the Sierra Leone civil war. Both Bintumani I and II were high pitched having been demanded by the citizens of Sierra Leone for the National Provisionary Ruling Council (NPRC) administration to negotiate peace with the Revolutionary United Front (RUF). Bintumani II was the

\footnotetext{
${ }^{4}$ African Charter on Democracy, Elections and Governance (2007); A Summary of Article $2 \& 3$ which speaks to the Objectives and Principles respectively.

5 Social Cohesion and Democracy by International Institute for Democracy and Electoral Assistance, (2009)
} 
ISSN (online): 2581-3048

product of citizens' demand for a multi-party general election in order to restore peace and civilian government instead of an extended military rule.

The national dialogue for peace and national cohesion (Bintumani III) was an election promise by the then presidential candidate Retired Brigadier Julius Maada Bio in case he won election (as he did now as the President noting):

"In the last ten years, the building blocks of national cohesion and the feeling of belonging of all citizens have gravely crumbled. The recent governance strategy has been characterized by tribalism, divisiveness, exclusion and the weakening and subversion of state governing institutions. There is a need to promote unity and national cohesion."

This statement was the building block for the Bintumani III.

\section{Democratization in Sierra Leone}

a. National Cohesion and Peace Consolidation efforts in Sierra Leone

Both past and present governments of Sierra Leone have made frantic efforts towards national unity and cohesion being the conduit for sustainable peace and democratic governance in the country. The most effort being the conveying of a national consultative dialogue on peace and national cohesion dubbed "Bintumani III".

It was discovered at the end of the three days dialogue conference participants that comprised all of works of life were concerned certain issues which they deemed to be impediments to the country national cohesion and peace consolidation strides and by extension a threat to Sierra Leone democratization process. The issues were as follows:

i. Lack of political will to implement progressive citizen-centered recommendations from past national consultative processes including Truth and Reconciliation Commission Report of 2004 and Constitutional Review Committee 2016;

ii. Misuse, abuse, and weak oversight of governance processes;

iii. Lack of accountability and transparency;

iv. Poor public service delivery;

v. Unfair, inequitable, unrepresentative and unjust allocation of public resources;

vi. Lack of representation or inclusion of women, children, youth, persons with disabilities across all spheres;

vii. Unfairness and unrepresentative employment practices; viii. Breaches of the Constitution and the lack of access to speedy and fair justice;

ix. Discriminatory access to land and natural resources;

x. Inflammatory and hate speech; and,

xi. Failures of decentralization

b. Democratic Institutions and Good Governance in Sierra Leone

Since the declaration of the end of the civil war in 2002, the Government of Sierra Leone establishes new institutions and overhauled existing ones that are deemed to be integral in consolidating the hard won peace as well as to promote democratic good governance with the exception of the National Commission for Democracy which was established in 1994 by the National Provisional Ruling Council's Decree no.15. Some of these institutions include but not limited to the following: The Human Right Commission of Sierra Leone (HRCSL); Political Parties Registration Commission (PPRC); National Electoral Commission (NEC); Office of the Ombudsman; Anti-Corruption Commission (ACC); Audit Service Sierra Leone; Sierra Leone Police; and Republic of Sierra Leone Armed Forces (formerly Sierra Leone Army) amongst others.

These institutions with support from Government should have been collaboratively implementing outstanding Truth and Reconciliation Commission Report recommendations and to ensure that existing relevant institutions and processes are effectively executed;

Enacting legislation for a predictable election timetable (fixed dates), a transparent post-election political transition process, and reviewing the role of paramount chiefs in the national legislature; as well as addressing fairness, equity and inclusion, representation for women and all other marginalized and disadvantaged groups in the democratic process- such as children especially the girl child, physically challenge, widows to name but a few.

The creation of the aforesaid institutions was in the spirit and belief that these institutions when established will live to stand the tests of time. It's imperative to note that the fundamental responsibility of any government in the world in respective of the Continent it located is to;

1. To create a platform of level playing field for equal opportunities and inclusion for its Citizens in the distribution and allocation of national resources, job opportunities that flow from the central government to the local government with a positive community based impact.

2. To make provision for its citizens by upholding and implementing macroeconomic objectives there by 
ISSN (online): 2581-3048

creating a platform to ensure a leverage on the status of citizens mitigating the risk of high level of inequality in society.

This role of Government in any country is very much crucial to execute for the enforcement of national unity, social cohesion and inclusiveness despite the diversities in; human livelihood, colour, socio-economic conditions, traditional and cultural background, religious and ethnic origins. - Whether rich or poor, old or young, able or disable, girl or boy, male or female, whether born in the urban cities or rural areas, educated or uneducated, whether marriage or single to name but a few. However, over the years political parties within the political environ have been volatile especially in the recent trends of events both in the erstwhile APC administration and the now SLPP administration which have left citizens pondering to perceive their existence to benefit all citizens in Sierra Leone putting national interest first as against personal interest.

This is evident in the past decades, political turmoil during elections and Post-elections for the Administrators in governance and in the most recent spate of hate speeches in social media among political actors and followers, violence and massacre of aggrieved citizens (illegal sacking of political actors and citizenry in the labour market); coupled with the abandoning of the processes that would have led to the birth of new constitution for Sierra Leone.

\section{POLICY RECOMMENDATIONS FOR ACTION}

i. In order to overcome the trends of weakened state and increased social inequality, it is prudent to establish new institutions that promote plurality and respect for diversity of opinion to ensure equity and inclusion and strengthen the old ones. That is to say government institutions in Sierra Leone should respond to the interests of the people without resorting to demagogy or false promises.

ii. Adopting an action plan that promotes, political tolerance, equality, inclusion and social cohesion is urgently needed to foster National security and Sustainable development in Sierra Leone. Given that the demands of the most disadvantaged population are not only spontaneous but largely perennial. Thus, it is necessary to reduce the disparities between those who have and those who have not, both in terms of income (economic right) as well as acknowledging the cultural, social and political right of other people (those with dissenting views and opinion). It is also worthy to acknowledge and applaud the Government of Sierra Leone's effort in conveying a Consultative National Dialogue on Democratic Consolidation for
https://doi.org/10.47001/IRJIET/2021.506002

Peace and National Cohesion in Sierra Leone, yet sixteen (16) months after the communiqué was presented to the President, nothing was heard or seen as tangible steps towards consolidating the country's hard-won peace, promote national cohesion and safeguarding the country's fledgling democracy.

iii. One of the major recommendations of the Bintumani III was that the Government of Sierra Leone should as a matter of urgency establishes a Peace Commission with a mandate that encapsulate three broad categories: Conflict Prevention; Management and Public Education about peace and Conflict Prevention. However, participants affirmed that the institution's mandate must not overlap with those of existing institutions.

iv. Lastly, Government should ensure all public policies to be research based especially those that nexus with issues relating to equity and inclusion, social cohesion, national unity and political tolerance.

The Public lectures ended with so many recommendations from participants as follows;

\section{Participants/ Audience:}

i. Public lectures that gear towards Political Tolerance, National Unity and Social Cohesion shouldn't be limited in urban cities and towns but also extended to Chiefdom levels.

ii. The Government and democratic partners to adopt an action plan that promotes equity, equality, inclusion and social cohesion is urgently needed to foster National security and Sustainable development in Sierra Leone.

iii. Financial support to be scaled up for the National commission for Democracy (NCD) for effective and efficient performance to meet the institutional desired output

iv. Parliamentarians should stop voting on party lines and try to put national interest first as against personal interest/party interest

v. Improvement on national development with more civic education to be done in Sierra Leone by the NCD

vi. Government should create a freedom and level playing field for media houses and social media

vii. Political tolerance to prevail between political winners and losers within the political landscape of Sierra Leone

viii. Capacitate democratic institutions to ensure the three (3) pillars working well. 
ISSN (online): 2581-3048

ix. The NCD to make available public lecture notes to Secondary schools, tertiary academic institutions and other communities in Sierra Leone.

\section{IMPLICATIONS FOR NATIONAL SECURITY AND SUSTAINABLE DEVELOPMENT}

It is an open secret that peace and security are inextricable parameters that stimulates and attracts the demand of foreign direct investments, cause a growth in Gross Domestic Product; and create a platform that enhances employment opportunities reducing the high employment rate in Sierra Leone. This in turn will have a trickled down effect on household income, purchasing power parity, standard of living and human livelihood in Sierra Leone. Thus, a government that promotes peace and national unity is by extension promoting sustainable socio-economic growth and development in Sierra Leone.

The antecedents of the 11 years civil war as encapsulated in the report of the Sierra Leone's Truth and Reconciliation Commission established in 2002 speak to the need for political tolerance, social inclusion, formation of governments of national unity (nationalistic) as well as the safeguarding of freedoms of expression, assembly and association to ensure democratic consolidation. Worth noting it that any attempt by state institution(s) to suppress these rights and freedoms will degenerate the country into state of negative peace ${ }^{6}$, which is not good for the country's fledgling democracy and consolidation of its hard won peace.

\section{CONCLUSION}

A peaceful and productive society is based on effective state institutions where the ideal of human right, good governance and democracy are upheld. Good governance in this sense means effective and efficient structures which provide optimal support to citizens to live a safe and productive life in line with their desires and opportunities. Essentially, this involves a combination of democracy, social welfare and the rule of law. The existence of a political order that is established freely and hinges on the universal human rights and democratic principles that allows for rules limiting the arbitrary use of power and privileges. It should uphold a system that guarantees the rights and freedoms of its citizens in a political order of justice and tolerance ${ }^{7}$. Sierra Leone as a political society must respect the principles of freedom, justice and tolerance in order to safeguard the peaceful coexistence of its members. Every citizen must acknowledge a good code of conduct that provides freedoms in a legal and institutional framework that is trusted by its citizens. A concept of freedom that inspires democracy must be based on the possibility of a decent life for all citizens, in a society where personal and collective life is not dictated by necessity but by a set of human rights. There is an urgent need for all state and nonstate actors to genuinely popularize the call for national unity and Social cohesion, a call that should be anchored on the consolidation of plurality of citizenship and reducing inequality and socio-economic disparities and fractures in the land that we love (Sierra Leone).

\section{REFERENCES}

[1] "African Charter on Democracy, Elections and Governance" (2007); African Union

[2] "African Charter on Human and People Rights" (1986); African Union.

[3] "Final Communiqué on the Consultative National Dialogue on Democratic Consolidation for Peace and National Cohesion in Sierra Leone" (2019); Government of Sierra Leone.

[4] "Sierra Leone's Population and Housing Census" (2015). Statistics Sierra Leone.

[5] "Social Cohesion and Democracy" (2009). International Institute for Democracy ad Electoral Assistance, Stockholm.

[6] "Truth and Reconciliation Report" (2004) Sierra Leone Truth and Reconciliation Commission.

URLs:

[7] https://www.giz.de/en/ourservices/governance and d emocracy.html

[8] https://www.must.ac.ke/nationalcohesion/\#: :text=N ational $\% 20$ Cohesion $\% 3 \mathrm{~A}$,enterprise $\% 20 \mathrm{and} \% 20 \mathrm{faci}$ ng\%20shared\%20challenges

\footnotetext{
${ }^{6}$ Negative Peace in the term used to describe the absence of large scale conflict or violence in country.

${ }^{7}$ African Charter on Human and Peoples Rights (1986)
} 


\section{Citation of this Article:}

Dr. Allieu Badara Kabia, Ibrahim Mansaray, "Political Tolerance, National Unity and Social Cohesion as a Tool for Democratic Consolidation in Sierra Leone" Published in International Research Journal of Innovations in Engineering and Technology IRJIET, Volume 5, Issue 6, pp 5-12, June 2021. Article DOI https://doi.org/10.47001/IRJIET/2021.506002 